\title{
A NEW AND SHOWY SPECIES OF LEPANTHES (ORCHIDACEAE: PLEUROTHALLIDINAE) FROM NORTH-WESTERN ECUADOR
}

\author{
Luis E. Baquero ${ }^{1,2, *}$, Tatiana Jaramillo-Vivanco ${ }^{2} \&$ Denisse Galarza Verkovitch ${ }^{2}$ \\ ${ }^{1}$ Grupo de Investigación en Medio Ambiente y Salud BIOMAS, Carrera de Ingeniería Agroindustrial y \\ Alimentos. Facultad de Ingeniería y Ciencias Agropecuarias. Universidad de Las Américas, \\ Calle José Queri, Quito 170137, Pichincha, Ecuador \\ ${ }^{2}$ Jardín Botánico de Quito, Pasaje \#34, Rumipampa E6-264 y Av Shyris, Interior Parque La Carolina, \\ Quito, 170135, Pichincha, Ecuador \\ *Author for Correspondence: lbaquero@hotmail.com
}

\begin{abstract}
A new species of Lepanthes from north-western Ecuador is presented here. Lepanthes mashpica is similar to $L$. satyrica, with a long, descending, triangular process of the body of the lip but different in the simple and acute appendix versus the vertically bilobed appendix of $L$. satyrica. The species was found growing in several locations of Mashpi Reserve, a low-land cloud forest close to Quito.

RESUMEN. Se presenta aquí una nueva especie de Lepanthes del noroeste de Ecuador. Lepanthes mashpica es similar a $L$. satyrica, con el cuerpo del labelo largo, descendente y triangular pero se diferencian en el apéndice simple y agudo del labelo en L. mashpica comparado con el apéndice verticalmente bilobado en L. satyrica. La especie se encontró creciendo en varias localidades dentro de la Reserva Mashpi, un bosque nublado de tierras bajas cercano a Quito.
\end{abstract}

Keywords / Palabras Clave: Ecuadorean orchids, Lepanthes mashpica, Lepanthes satyrica, orquídeas del Ecuador, Mashpi Reserve, Reserva Mashpi

Introduction. New species of Lepanthes Sw. are discovered each year at the orchid rich country of Ecuador (Dodson 2004, Baquero et al. 2018, Tobar et al. 2018, Baquero 2018, Thoerle \& Hirtz 2015). The genus, with more than 1,100 species, is one of the largest in the Orchidaceae (Karremans 2016). The species of Lepanthes are recognized by the ramicauls enclosed by lepanthiform sheaths, flowers with transversely expanded petals with two or three lobes, a complex lip (with some exceptions) with a body connecting a pair of blades which normally embrace the column, and a very small structure at the base of the lip called the appendix (Luer 1996). The appendix is present in species which are pollinated by small gnats under the pseudo-copulation syndrome where the male insects confuse the structures with the female genitalia and pollinate the orchids under the attempt to copulate (Blanco \& Barboza 2005).

Some species have lips with simple structures and without appendixes. Such is the case of species like Lepanthes calodictyon Hook., or the recently discovered L. kayii Baquero (Luer 1996, Baquero 2018). Other species of Lepanthes have complex lips with appendixes but also other unique structures of the lip. Lepanthes ollaris Luer \& R.Escobar has a body of the lip greatly dilated and saccate into a pot-like structure, $L$. menatoi Luer \& R.Vázquez and L. ricina Luer \& Daltröm have lips with the inner surface of the blades with curtains of long pubescence covering the column (Luer \& Thoerle 2011). Some species have a body with a long protruding, descending process like Lepanthes satyrica Luer \& Hirtz from Ecuador. A species discovered in 2016 and described here has also a long descending process from the body of the lip similar to what is seen in Lepanthes satyrica.

The new species was found growing in low-land cloud forest of Mashpi Reserve from north-western Ecuador, Pichincha Province. The Mashpi Lodge, built in the heart of the Mashpi Reserve, has no previous research concerning orchids. The new species presented here is an example of how little is known of the orchids from Mashpi Reserve.

\section{TAXONOMIC TREATMENT}

Lepanthes mashpica Baquero \& T.S.Jaram, sp. nov. (Fig. 1-4B)

TYPE: Ecuador. Pichincha: Reserva Mashpi, 1000 m, 0`9'30.6”N, 7853'7.8”'W, 13 September 2017. L. Baquero, T. Jaramillo. LB 3145 (holotype: QCNE). 


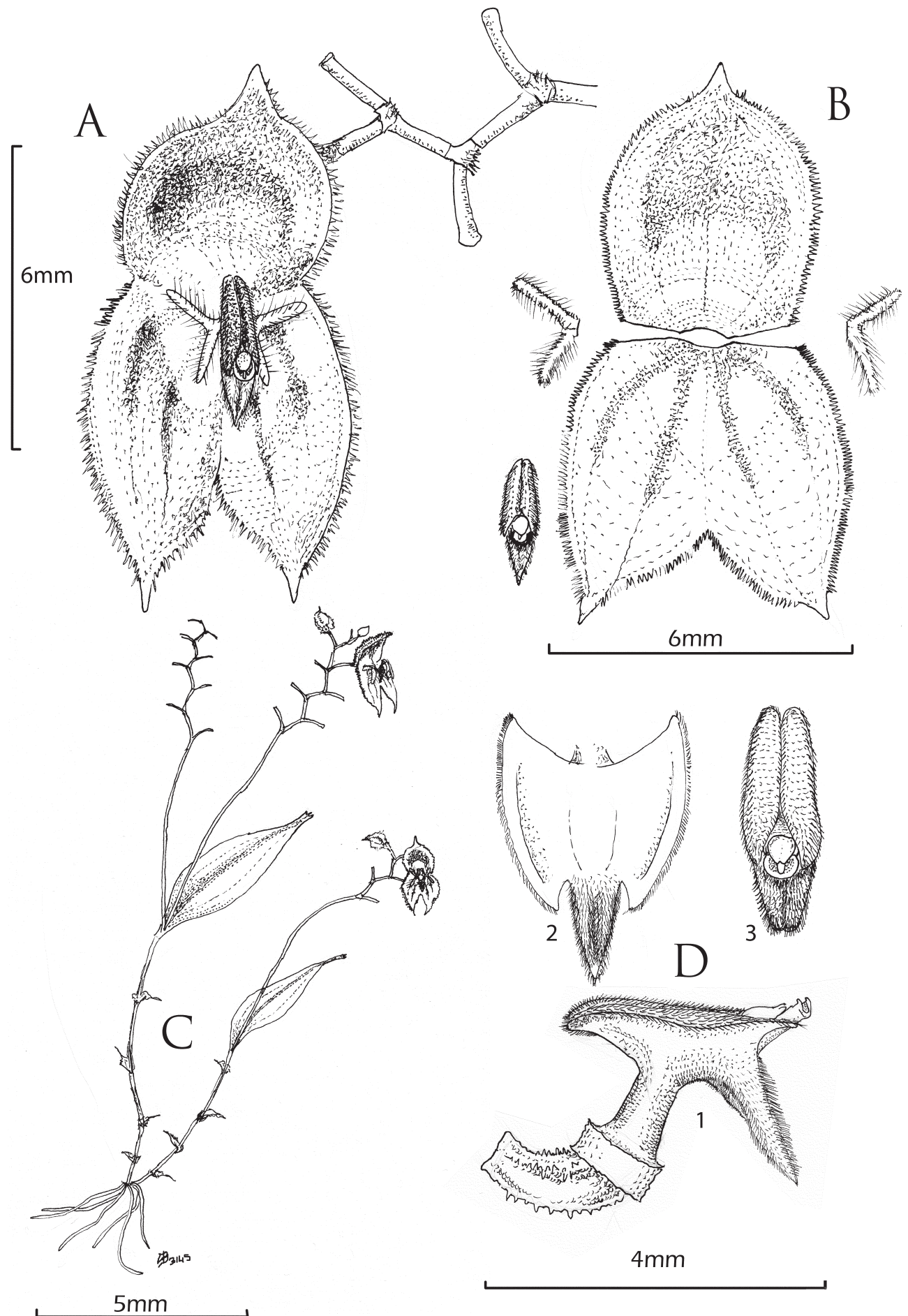

Figure 1. Illustration of Lepanthes mashpica Baquero \& T.S.Jaram. A. Flower. B. Dissected perianth. C. Habit. D. Column and lip. D1. Ovary, column and lip, side view. D2. Lip in expanded position. D3. Lip in normal position. Drawn by Luis E. Baquero from the plant that served as the holotype. 

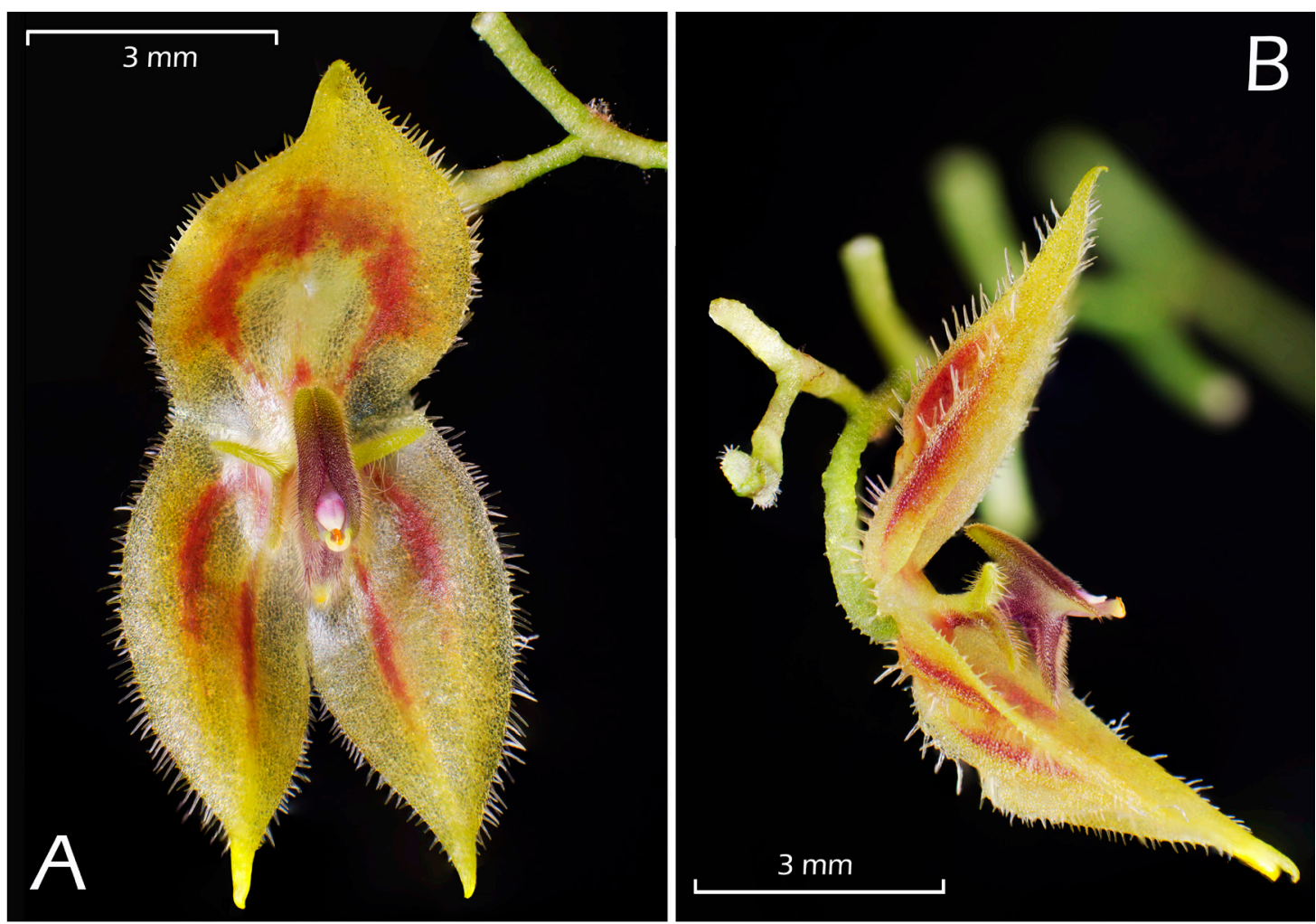

Figure 2. Photographs of the flower of Lepanthes mashpica Baquero \& T.S.Jaram. A. Frontal view. B. Lateral view. Photographs by Luis E. Baquero.

Diagnosis: Lepanthes mashpica is most similar to L. satyrica Luer \& Hirtz, both bearing a lip with an elongated, descending, triangular process. Lepanthes mashpica is distinguished by the spiculate margins of the sepals (vs. minutely cellular-denticulate), the long-pedicellate, inflorescence, successively severalflowered raceme, borne near the apex of the leaf (vs. short inflorescence, successively few-flowered raceme, borne close to the base of the leaf), the petals very small, transversely bilobed, upper and lower lobes similar in size and shape, narrowly oblong, hispid (vs. transversely bilobed petals with a minute apiculum on the margin between the lobes, the upper lobe long-pubescent, the lower lobe, short-pubescent), a lunate and curved apex of the rostellum (vs. truncate, straight apex of the rostellum) and the appendix simple, acute and pubescent (vs. vertically bilobed appendix) (Fig. 1-3).

Plant epiphytic, sympodial, caespitose herb up to $10 \mathrm{~cm}$ tall. Roots ca. $0.7 \mathrm{~mm}$ in diameter. Ramicauls slender, erect to horizontal, elongated, thin, $1-4 \mathrm{~cm}$ long, enclosed by 5-9 apiculated at the apex, acuminated, tightly fitting acuminate lepanthiform sheaths. Leaf green, thinly coriaceous, narrowly ovate, acute, the base cuneate, the apex tridentate, lightly-sulcated at adaxial side, $2.8-3.5 \times 1.2-1.5 \mathrm{~cm}$. Inflorescence a lax, distichous, flexuous, successively flowered raceme up to $50 \mathrm{~mm}$ long, including the rachis, borne by a filiform peduncle $25-35 \mathrm{~mm}$ long, erect; floral bracts spiculate, $0.7 \mathrm{~mm}$ long; pedicels $3 \mathrm{~mm}$ long. Ovary costate, spiculate, $1.0-1.3 \mathrm{~mm}$ long. Flower with sepals translucent yellow suffused with orange, petals yellow, column rose, and lip yellow suffused with red, orange and purple, the apex of the rostellum yellow, anther cap rose. Sepals carinate and spiculate along the veins on the abaxial surface. Dorsal sepal glabrous at the adaxial side, spiculate at the margin, broadly obovate, acuminate, shallowly concave, 3 -veined, broader than the lateral sepals, $7.1 \times 4.5 \mathrm{~mm}$, connate to the lateral sepals for $1.4 \mathrm{~mm}$. Lateral sepals glabrous, spiculate at the margins, ovate, acuminate, connate $2.3 \mathrm{~mm}$ into a synsepal, $7.5 \times 4.1 \mathrm{~mm}$, each individual sepal free for 

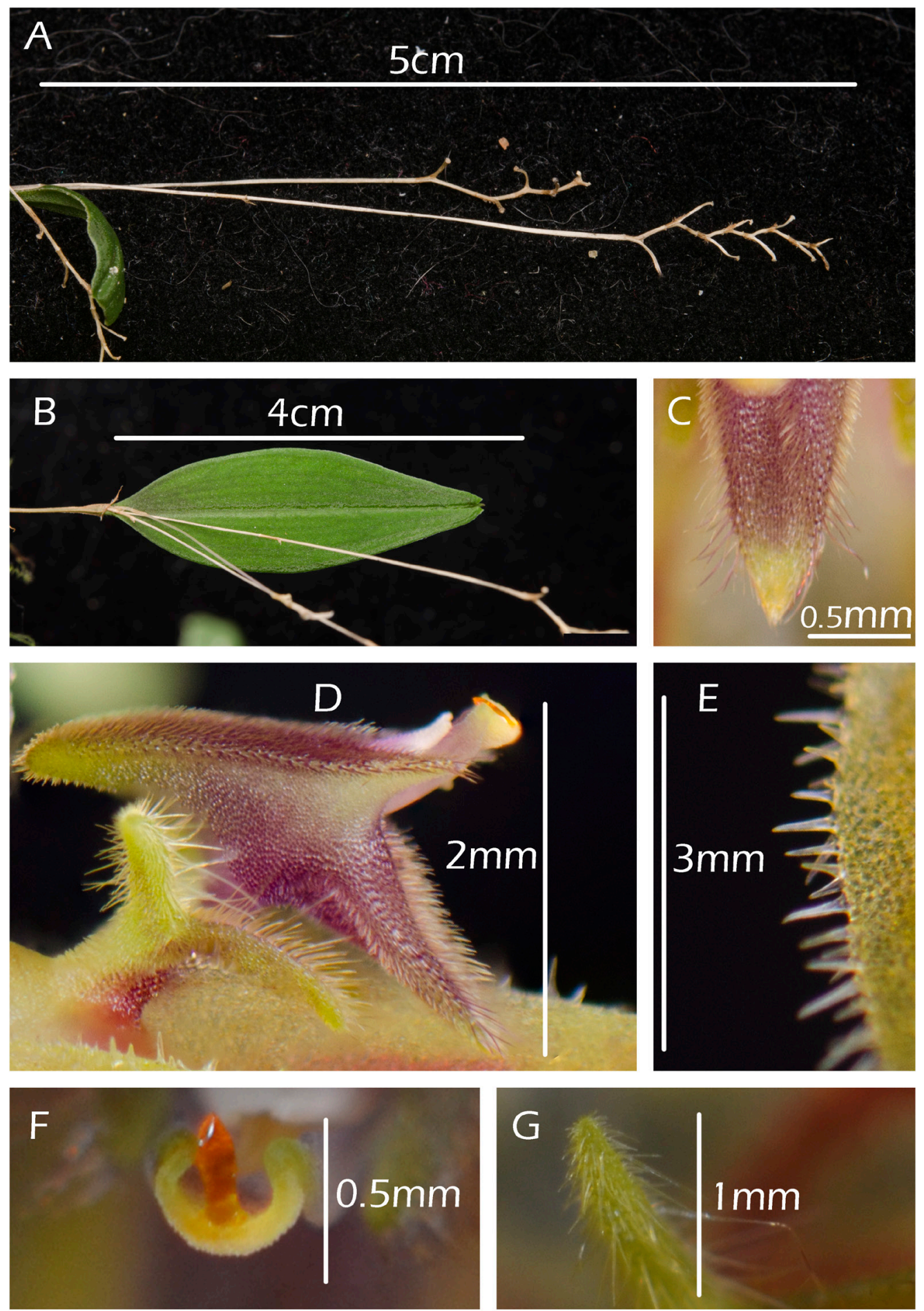

FIGURE 3. Details of Lepanthes mashpica Baquero \& T.S.Jaram. A. Flexuous inflorescence and peduncle. B. Leaf from dorsal view. C. Apendix. D. Side view of lip and column, E. Spiculated margins of sepals. F. Detail of lunate rostellum. G. Hispid upper lobe of a petal. Photographs by Luis E. Baquero. 

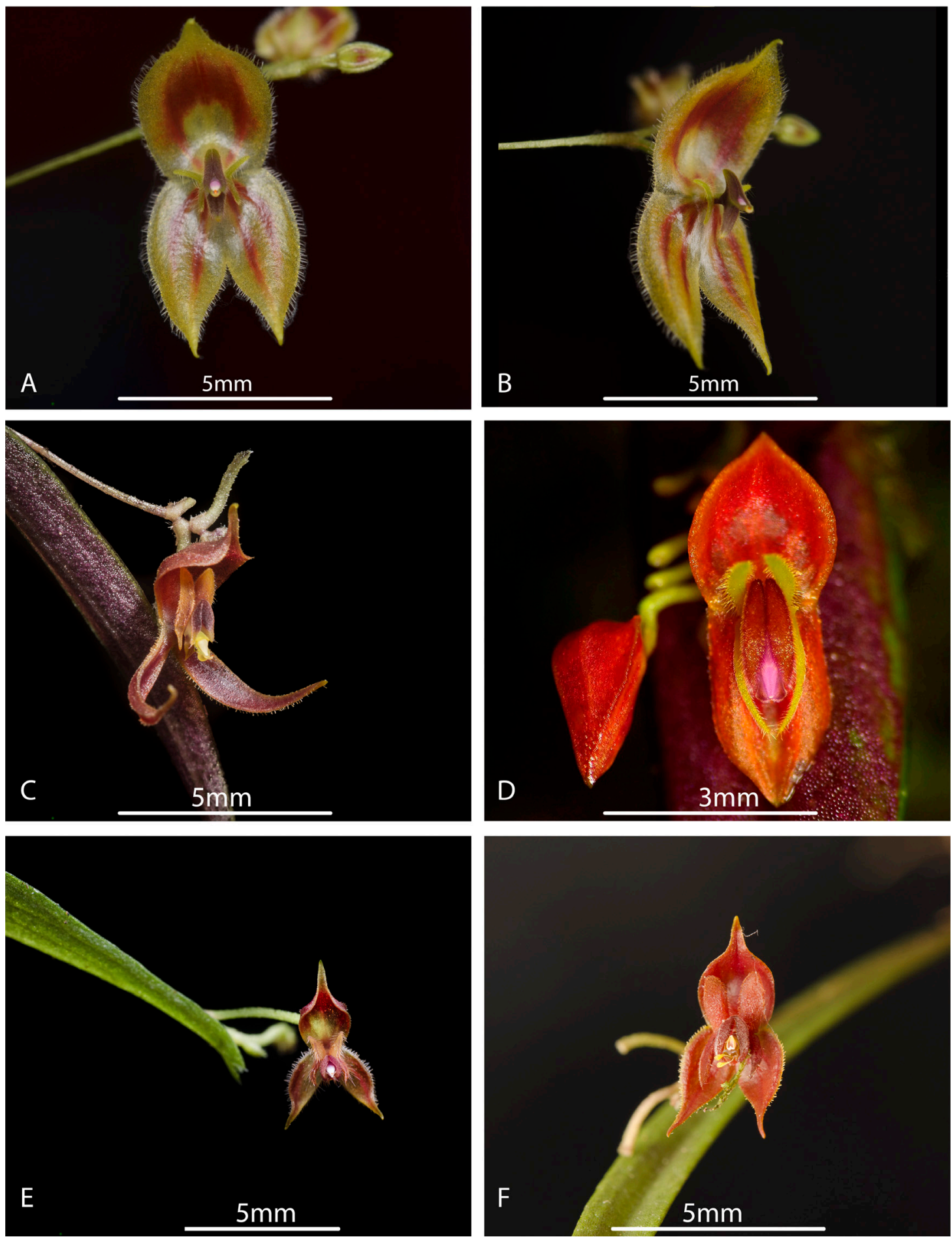

FIGURE 4. Comparison of the most similar species to Lepanthes mashpica Baquero \& T.S.Jaram. A. Lepanthes mashpica (frontal view). B. Lepanthes mashpica (3/4 view). C. Lepanthes acrogenia, D. Lepanthes satyrica, E. Lepanthes hirsutula, F. Lepanthes thoracica. Photographs by Luis E. Baquero (A, B and F), Sebastian Moreno (C and E), and Andreas Kay (D). 
ca. $3 \mathrm{~mm}, 2$-veined. Petals transversely bilobed, hispid (with long, rigid hairs), the lobes linear, $0.12 \times 2.60$ $\mathrm{mm}$, the upper lobe $1.2 \mathrm{~mm}$ long, the lower lobe 1.4 $\mathrm{mm}$ long. Lip bilaminate, the blades oblong, touching for two thirds of their length, acute, slightly curved, and separated towards the apex of the column, pubescent, $2.8 \mathrm{~mm}$ long; the connectives broadly cuneate, oblique, connate above the base of the column, $0.8 \mathrm{~mm}$ long, the body with and elongated, descending, triangular, densely pubescent process $1.7 \mathrm{~mm}$ long, with an acute, yellow, pubescent appendix. Column terete, $1 \mathrm{~mm}$ long, the anther dorsal and stigma ventral, the apex of the rostellum conspicuous, lunate, curved. Anther cap obovate, $0.3 \mathrm{~mm}$ long. Pollinia 2, pyriform, attached to a detachable viscidium, $0.3 \mathrm{~mm}$ long. Capsule not seen.

Toponymy: Named after Mashpi Reserve where it was first found and thrives.

Habitat AND ECOlogy: Lepanthes mashpica is so far, endemic to the Mashpi Reserve and grows close to Mashpi Lodge. It was first found in 2017 very close to the lodge, at $1000 \mathrm{~m}$ in elevation growing on a fallen branch near the "Magnolia trail". After years of research, more plants have been found growing in Mashpi Reserve at different elevations between 800 and $1200 \mathrm{~m}$. This species has been seen growing with other species of pleurothallids like Lepanthes bituberculata Luer \& Hirtz, L. pretiosa Luer \& Hirtz and Pleurothallis ruscifolia (Jacq.) R.Br. sometimes in the same branch. It has always been found growing in slender branches and adult plants rarely having more than three ramicauls. Although no fruits have been seen it is common to see adult and seedlings growing together which means the species gets pollinated frequently and reproduces easily from seed in its habitat.

Phenology: This species has been observed blooming at its habitat, in different months during consecutive years. It appears to bloom all year round.

This species has relatively big flowers for the genus and pretty color combination. The long inflorescences bear one open flower at a time, successively producing up to 10 flowers on each inflorescence. Due to the long process of the body of the lip, the concave and wide dorsal sepal, and the connate lateral sepals Lepanthes mashpica is most similar to Lepanthes satyrica from farther north but it is easily distinguished by the comparatively bigger flowers blooming from long inflorescences, longer than the comparatively wider leaves. Other characteristics, less obvious, like the different shape of the appendix (slender and acute in L. mashpica vs. vertically bilobed in L. satyrica) or the petals (very small in proportion to the rest of the flower, bilobed with two finger-like upper and lower lobes in L. mashpica vs. bigger in proportion to the rest of the flower with and apiculum between the lobes in L. satyrica) immediately distinguishes both species (Luer 1996, Luer \& Thoerle 2011) (Fig. 3-4).

Other species of Lepanthes have a long process in the body of the lip like L. acrogenia Luer \& R.Escobar, L. ectopa Luer, L. hirsutula Luer \& Hirtz, L. skeleton Luer \& R.Escobar, and L. thoracica Luer \& Hirtz, but L. mashpica can easily be distinguished from them by the bigger and yellow flowers with conspicuously spiculated flowers in the margins and in the adaxial side of the sepals with tiny filiform, bilobed petals (Luer 1996, Luer \& Thoerle 2011, 2012) (Fig. 3-4).

Conservation Status: Several and healthy populations have been found along the years close to Mashpi Lodge and all grow within the Mashpi Reserve limits. The species is not considered to be under risk of extinction for some time in the future. We suggest to place it under the IUCN "Data Deficient" category since it might grow even outside Mashpi Reserve and there is not enough information to assure it is under threat at the moment.

ACKNOWLEDGEMENTS. The authors wish to thank Mashpi Lodge and the Grupo Futuro for the support provided in this research and for helping in the conservation of an important remaining forest in the low-lands of the western Andes of Ecuador. We acknowledge Universidad de Las Americas (UDLA) for funding orchid research in Ecuador. The Ministerio del Ambiente del Ecuador is acknowledged for issuing the Environmental Research Permit No. 008-2016-IC-FLO-DNB/MA. We thank Andreas Kay and Juan Sebastian Moreno for using their photos in this article. We also thank Ana Lofredo for her language corrections. Finally, we are grateful to the Editor and the anonymous reviewers for suggestions on the manuscript. 


\section{Literature Cited}

Baquero, L. E. (2018). A new species of Lepanthes (Orchidaceae: Pleurothallidinae) from northwestern Ecuador. Phytotaxa, 343(1), 75-81.

Baquero, L. E., Moreno, J. S. \& Iturralde, G. A. (2018). The Four Footed Lepanthes (Pleurothallidinae), a new species from north-western Ecuador. Lankesteriana, (18)3, 183-188.

Blanco, M. A. \& Barboza, G. (2005). Pseudocopulatory pollination in Lepanthes (Orchidaceae: Pleurothallidinae) by fungus gnats. Annals of Botany, 95(5), 764-772.

Dodson, C. H. (2004). Native Ecuadorian Orchids II: Dresslerella-Lepanthes. Quito, Ecuador: Imprenta Mariscal.

Karremans, A. P. (2016). Genera Pleurothallidinarum: an updated phylogenetic overview of Pleurothallidinae. Lankesteriana, 16(2), 219-241.

Luer, C. A. (1996). Icones Pleurothallidinarum XIV. Systematics of Draconanthes, Lepanthes subgenus Marsipanthes and subgenus Lepanthes of Ecuador. Monographs in Systematic Botany from the Missouri Botanical Garden, 61, 1-255.

Luer, C. A. \& Thoerle, L. (2011). Lepanthes Sw. and affiliates. In C. Persson \& B. Stahl, Flora of Ecuador, 88, $13-405$. Goteborg: Botanic Institute, Goteborg University.

Luer, C. A. \& Thoerle, L. (2012). Icones Pleurothallidinarum XXXII. Lepanthes of Colombia (Orchidaceae). Monographs in Systematic Botany from the Missouri Botanical Garden, 123, 1-296.

Thoerle, L. \& Hirtz, A. (2015). Three new Lepanthes species (Pleurothallidinae, Orchidaceae) from Ecuador. Phytotaxa, 201, 50-62.

Tobar, T., López, M. F., Muñoz-Upegui, D. \& Richter, F. (2018). Two new species of Lepanthes (Pleurothallidinae; Orchidaceae) from Andean forest remnant in Ibarra, Ecuador. Phytotaxa, 375(3), 221-228. 
